\title{
THE CULTURAL AND ARCHITECTURAL HERITAGE OF THE BANTEN GRAND MOSQUE, INDONESIA
}

\author{
A. BAHAUDDIN ${ }^{1} \&$ T.E. DARMAYANTI ${ }^{2}$ \\ ${ }^{1}$ School of Housing, Building and Planning, Universiti Sains Malaysia, Malaysia. \\ ${ }^{2}$ Department of Interior Design, Universitas Kristen Maranatha, Indonesia.
}

\begin{abstract}
The Banten Grand Mosque (BGM) is located within the complex of the Grand Mosque of Old Banten or Oud Bantam, in a strategic position at the western end of the island of Java, Indonesia. Banten's history has been influenced by various religions such as Hinduism, Buddhism and Islam. It led to the unique creation of the architecture of the BGM in an area where religious, social and political activities have been upheld since the reign of the Sultanate of Banten until today. The Grand Mosque of Banten is listed as one of the ancient mosques in Indonesia, dating from 1552, built by Sultan Maulana Hasanuddin, the first Sultan of Banten, during the time of the spread of Islam. The research, employing exploratory qualitative investigation with the support of literature on Banten, was conducted to determine the influence of animism and Hinduism-Buddhism before Islam onto this architecture, ascertained during field surveys and interviews with relevant individuals. The various religious and cultural influences are closely linked with the philosophies found in design elements, especially in the design of the column stumps (umpak). The research findings portrayed the stages of meditation in Buddhism, reflected in the curves of the lotus form in the interior of the mosque. Interestingly, the basic shape of the roof of the mosque depicts the Islamic philosophical approach related to the level of the universe, which was previously known as a Hindu philosophical approach: a representation of Meru, the sacred mountain. The BGM exhibits an architecture that is rich with assimilated cultural understandings and heritage.

Keywords: architectural components, Banten Grand Mosque, Hindu-Buddhist, Islam.
\end{abstract}

\section{INTRODUCTION}

The Banten Grand Mosque (BGM), Sunda, was built at the time of the coming of Islam into the province of Banten, during the reign of Sultan Maulana Hasanuddin, the first Sultan of the Sultanate of Banten. He was the son of Sunan Gunungjati - one of the Wali Songo (Nine Apostles of Islam) in West Java. The BGM is located within the Grand Mosque of Banten Complex, Banten Lama area (Fig. 1). It is the only artefact of the Sultanate of Banten that survives till today. This research focuses on the elements of architecture and interior design of the mosque, namely, the column stump (umpak) representing the foot of the building and the roof of the mosque representing the head of the building. There has been a lot of research undertaken on the BGM, but none has investigated these elements in depth from a cultural angle.

The existence of cultural elements in a building is always based on the history of the building's surrounding areas. The building is embedded with cultural and religious influences that occurred through time in relation to the surrounding context. The BGM, based on its geographical position, is in the area of Banten Lama (Oud Bantam), which was a part of the Hindu Kingdom of Padjajaran in West Java. Therefore, the architecture of the BGMshould have been influenced more by Hinduism (Minaham [1]), but the cultures of Central and East Java were perceived to have more influence in the architecture of this building. 


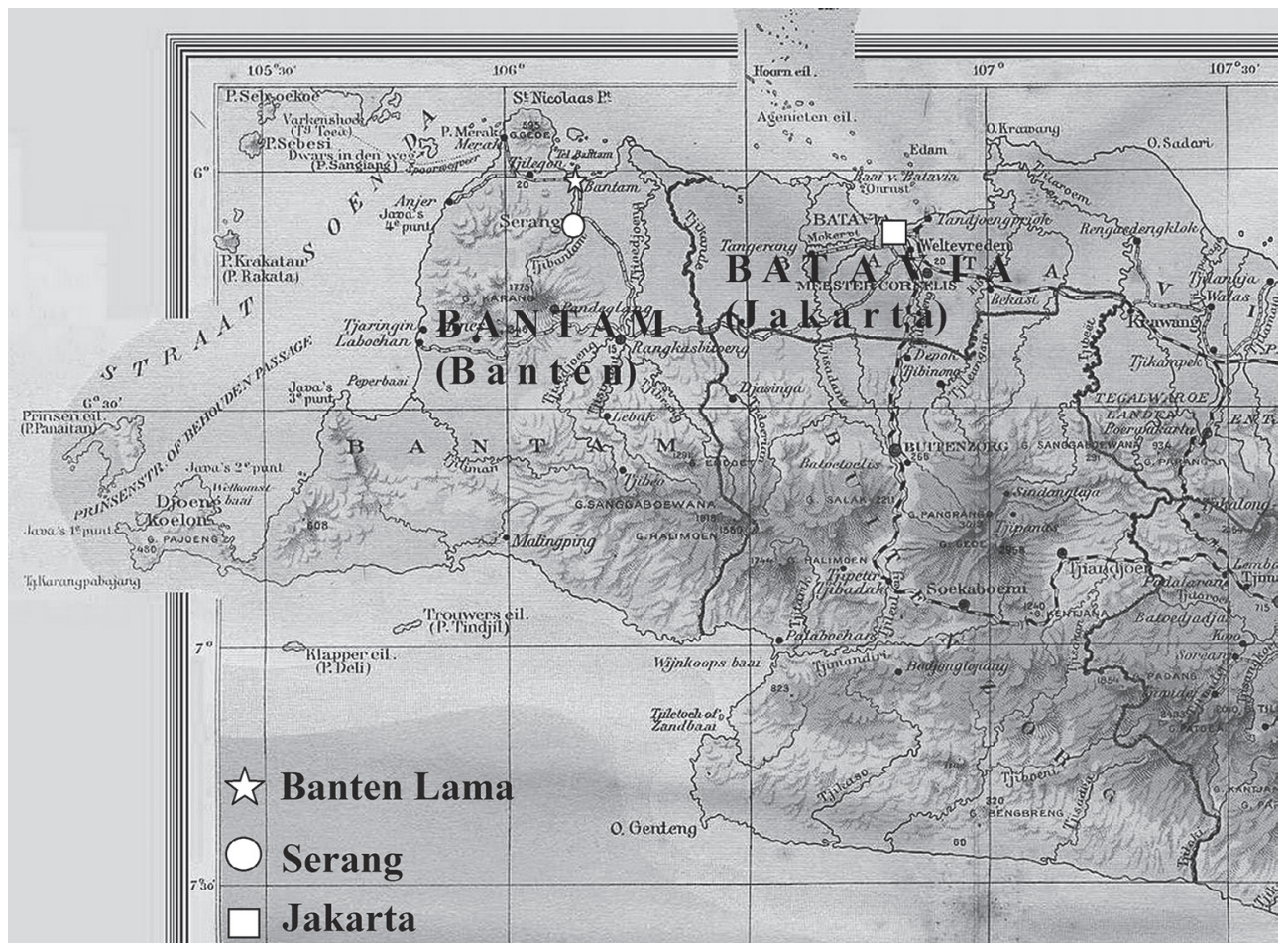

Figure 1: Grand Mosque of Banten location map, Banten, Indonesia.

\section{METHODOLOGY}

The influx of Demak Muslims from central Java with the aim of taking control of the Hindu Kingdom of Padjajaran created a strong influence of Javanese culture and Islamic religious beliefs in this area. This influence happened on top of the Hindu-Buddhist Kingdom of Padjajaran that had settled in Banten earlier (Tjandrasasmita [2]). The integration of Sundanese and Javanese cultures gave rise to a distinctive culture and language in Banten. The literature review with an ethnographic approach to cultural studies forms the framework of this research. It assists in revealing the philosophies of religion and culture found in the elements of architecture and interior design of the BGM. This is further helped by interviews, observations, survey and visual data collection processes in acquiring information, especially on the cultural beliefs. The mixing of various cultures and religions spawned a unique culture, a mixed philosophy of Hindu-Buddhist beliefs and the religion of Islam.

\section{THE GRAND MOSQUE OF BANTEN}

In Javanese culture, a building is divided into three parts to represent the human body, namely, the head, body and foot (Setyoningrum [3]). The head represents the roof, the wall or pillar symbolises the body and the stumps are the feet of the building (Fig. 2).

The umpak at the base of 24 internal main columns (tiang soko) of the BGM are octagonal in shape, to support the roof and are also a part of the building, the body. The roof or the head of the mosque is formed in joglo style, a traditional Javanese roof (Ismunandar [4], Tjahjono [5]). This typical terraced roof design is always used for roofs in ancient mosques in Indonesia. Previous investigations on the BGM have also provided opinions on the cultural influence of 


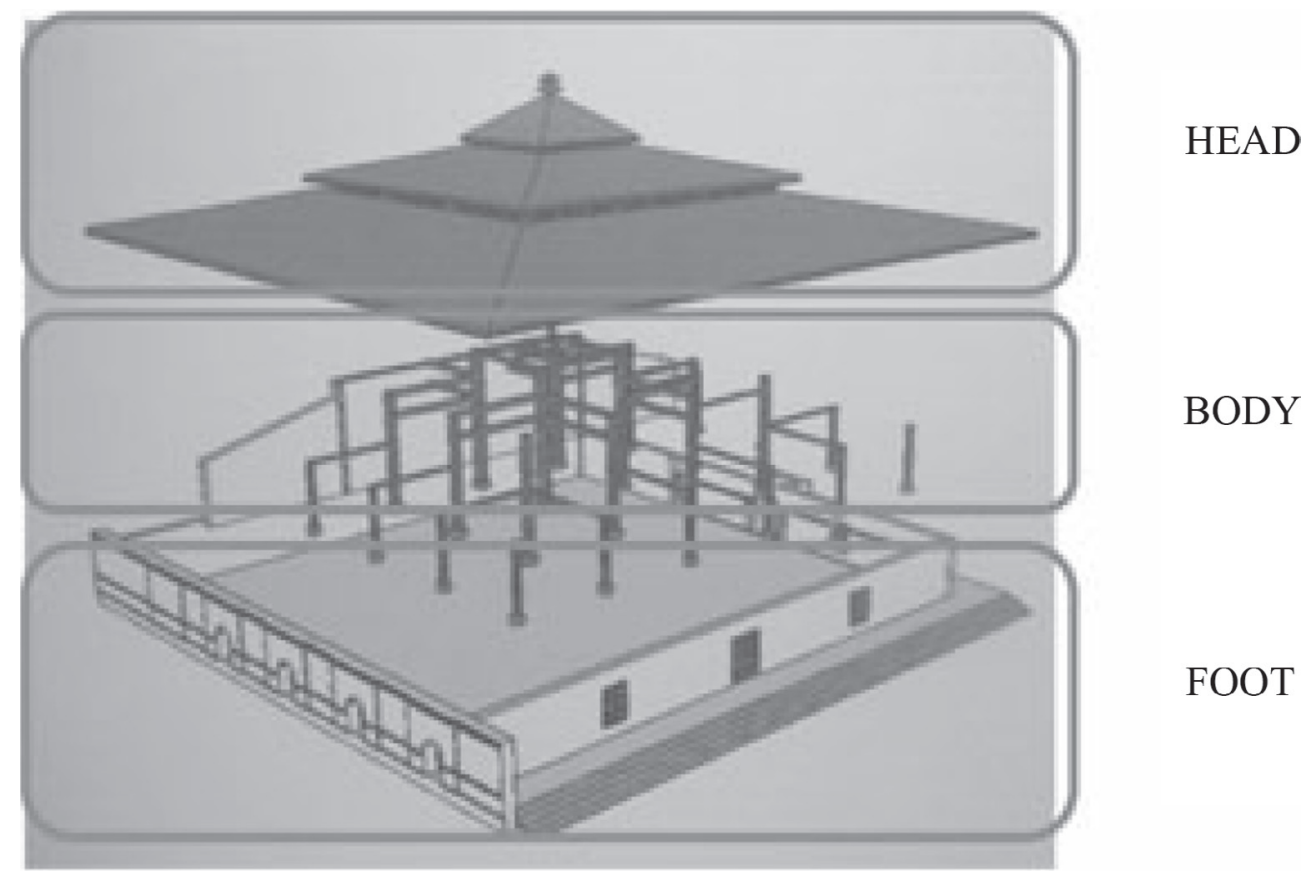

Figure 2: Representation of human body in relation to the mosque.

roof elements and bases that are embedded within Islamic philosophy, also confirmed during an interview with Kurdie [6], a Bantenologist, in 2011. He stated that the levels found in the BGM roof represent the characteristics of a Muslim faith.

The Muslim faith featured on the roof levels are as follows: the bottom level in a large roof represents all Muslims (Muslimin); the roof of the second level, which is smaller than the first one, represents the Faithful (Mukminin); the third-level roof, with a size smaller than the second one, represents the Benefactor (Muhsinin); the fourth-level rooftop, which is smaller than the third level, represents the Sincere (Mukhlishin); the fifth-level roof represents the Cautious (Muttaqin). However, the above information has raised many questions. Is Islamic philosophy the only philosophy that can be found in the roof of the BGM? Would this roof have other religious beliefs related to it? Does the basic form of the roof (the triangle) have a philosophy other than as one representative of Meru (mountain) alone?

The previous research also highlighted that the stumps (umpak) came from the shape of a pumpkin. Would there be any other beliefs related to the shape of the base other than a pumpkin? The BGM is an Islamic religious building, and the elements of architecture and the interior design philosophy have always been related to religious activities. However, it is an interesting fact that it also contains the philosophy of Hinduism-Buddhism due to the surrounding areas' influence on this religious building.

\section{TIERED ROOF AND COLUMN BASE (UMPAK)}

When spreading Islam, the propagators (wali) chose the strategy of culture. It had the goal of imparting Islamic knowledge without maligning other peoples' religious beliefs. This was done in order to create a keen study of Islam without concerns among the people regarding their beliefs. It indirectly affected the cultural elements of the BGM. 


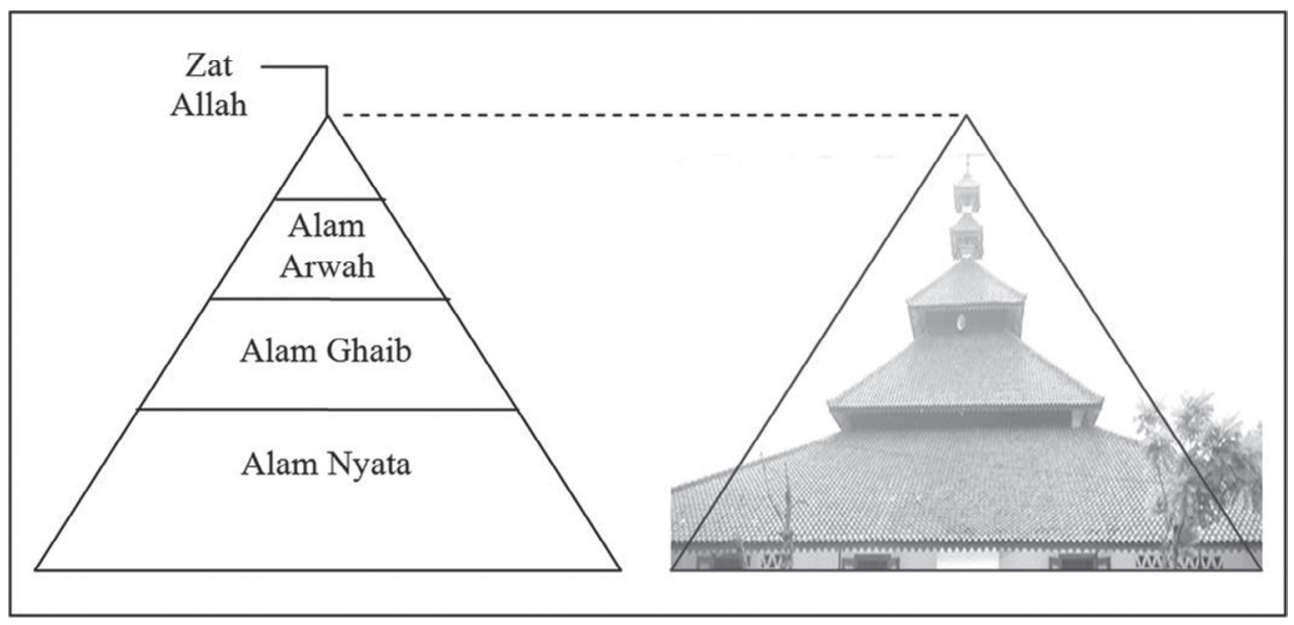

Figure 3: Roof level according to Islamic beliefs.

The roof also has a deep meaning in Islam, and it is not only in Hinduism that it is regarded as a representative of Meru, the sacred mountain. The basic shape of the roof is triangular. The apex of the triangle symbolises the highest point and the position of the Creator, Allah. This explanation can be described as the universe is depicted as a triangle, divided into four areas (Fig. 3), namely, Alam Nyata/Shahadah (the real world), Alam Ghaib/Mithal (the unseen world), Alam Arwah (the spiritual world) and Zat Allah (the Divine Essence), the point of great strength (Bahauddin [7]).

The triangular shape in the theoretical approach by Bahauddin [7] can also be seen in the roof top covering (memolo - red square). It is in the form of a bamboo shoot, which has the basic shape of a triangle (black triangle, Fig. 4). The highest end of memolo is represented as the

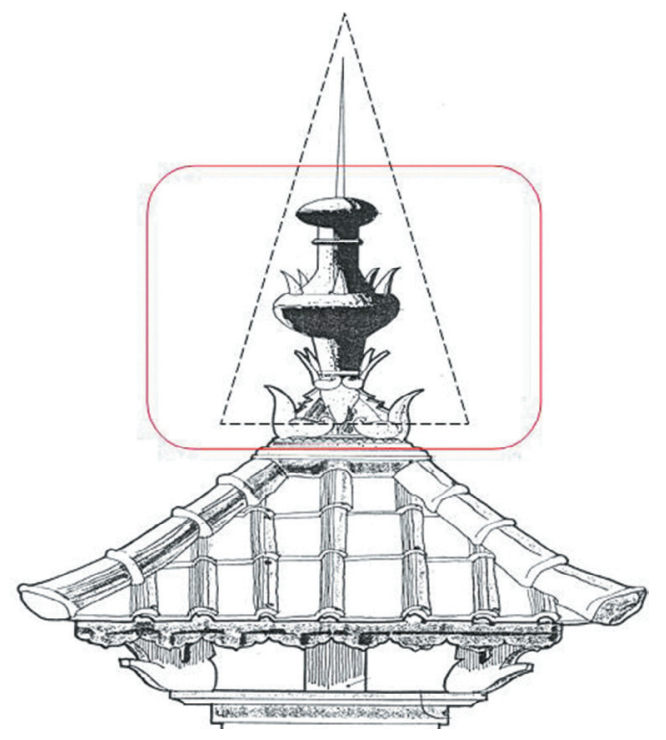

Figure 4: Bamboo shoot shape on memolo. 
highest place of the Creator of the universe. The statement about the form of the bamboo shoot is closely connected to the divine meaning expressed by Mohamad cited in Bahauddin [7], which has some relevancy to this study. He stated that the form of the bamboo shoot is an expression of the beauty of the universe that is derived from 'something' beautiful, referring to the Divine Essence.

The symbol of 'birth' is represented by the 'feet' or umpak found in the BGM, which are the solid foundations of a building as the bases could give 'life' to a building by holding it together. Umpak denotes a position and also points to a shift from a horizontal plane (land) to a vertical configuration (heaven) (Setyoningrum [3]). Meanwhile, the floor is a symbol of human existence between earth (ground) and heaven (Allah). In the interior of the BGM, there are 24 column stumps (umpak) placed at the centre of the mosque, with all 24 columns supporting the roof, the 'head' of the building. Specifically, the number of columns erected was based on the number of curved rib-like shapes found on the column stumps (Fig. 5).

There are 10 columns with 16 curved-rib column stumps, 8 columns that are supported by 18 curved-rib column stumps, only 2 columns with 24 curved-rib column stumps and 4 main columns (soko guru) with 48 curves. The column stump is shaped like a pumpkin with detailed lotus motif at its top and bottom. The lotus symbolises the 'birth' of Islam in Indonesia. It also represents the 'birth' of those who had just converted to Islam in the early days of the rise of Islam in Indonesia. It is a symbol of 'strength' to send prayers to emotionally and spiritually support the converted Muslims as they embark on a new life.

Above all, the lotus flower is perceived as a supporter of life, a supporter of the world and a symbol of life that brings about births (Snodgrass [8]). Historically, the column stump was seen as having the shape of a pumpkin, a fruit that has a deep meaning for the people of Banten. It had saved the people by being a major food source during the dry season. Thus, the shape of pumpkin was used as the main shape of the 24 column stumps, to indicate the

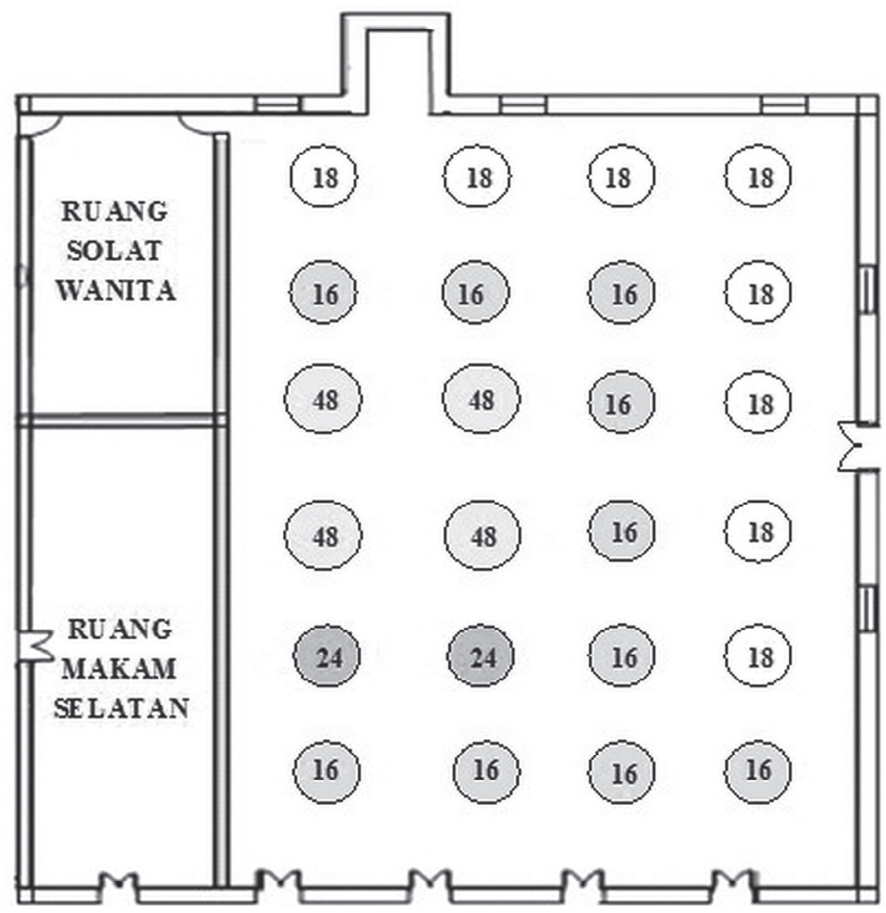

Figure 5: Umpak locations based on number of curves. 
struggle and the 'rebirth' of Banten (Kurdie [6], Yadi [9]). The juxtaposition of the representations highlights the cultural beliefs that governed the design of the architectural components of the mosque.

Additional analysis of the column stump with a lotus or pumpkin shape points to the circular motion of both shapes around the base. The circle is a symbol of the focusing of energy. It has a Chinese cultural approach with the philosophy of Buddhism. The column stump when viewed from the perspective of three dimensions becomes a round shape representing the 'world'. The round shape creates a balance of forces from all directions, not just on one strength (Govinda [10]). Circular forms at the foot of the column provide balance and strength in space. Viewed from a deeper meaning, it can be related to the focal point of prayers sending energy through the columns of the mosque to the highest point, heaven (Fig. 6). From a philosophical approach, the detailed column stump finds its compatibility in the philosophy of Buddhism through the Buddhist meditation layers known as the sixty levels. Its existence is seen most perfectly in the largest Buddhist temple and stupa in the world, the Borobudur temple in Central Java, Indonesia (Govinda [10]).

The levels of meditation have names that are typical of Sanskrit. There are four levels (16, $18,24,48)$, the amounts that are also found in the curved column stumps in the BGM. The name of the four special numbers taken from the level of meditation is Samadhindriyam (16th stage) or the meditation level. It is reflected in the 16 curved column stumps. Furthermore, the Saddhabalam stage (18th stage), meaning the strength of faith or aqidah in Islam, is known as kata. It is represented by a column stump with 18 curves. Dhammavicaya is the 24th stage of the Buddhist meditation level. It means seeking the truth, also represented by 24 curved column stumps, and the Tathagata (the 48th stage) is reflected in the four main columns (soko guru) that have 48 curves to bring the meaning of discovering the truth (Fig. 7).

During the field observation process, it was found that there are 24 columns that are not located in the centre of the room. Generally, the main column should be located in the middle of the room. However, they could not be located in the middle of the room due to the introduction of a women's prayer room (pewastren) and a tomb. The pewastren was built between 1580 and 1596 (Yadi [9]). Through a simulation plan of the column positions without the

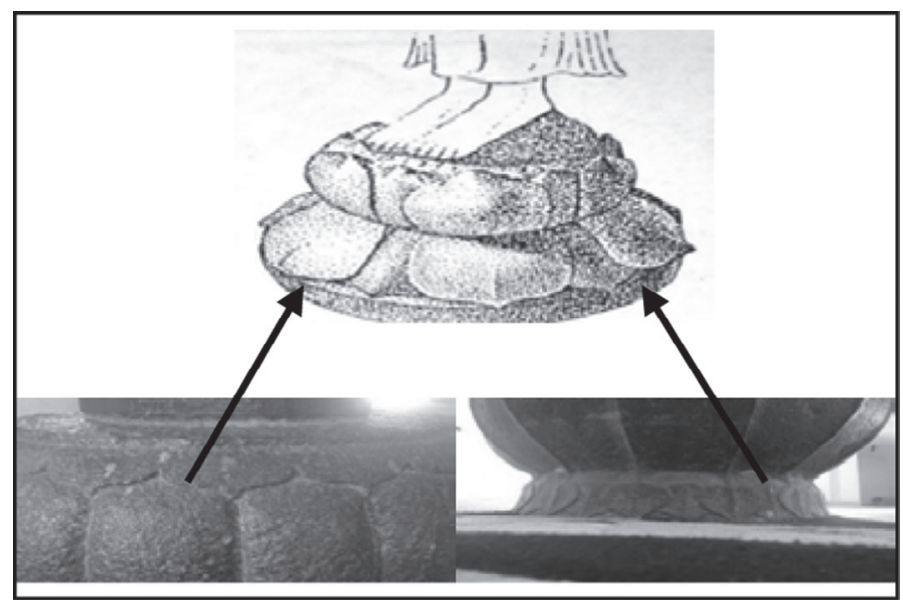

Figure 6: Lotus motif on umpak. 
Islamic Heritage Architecture 35

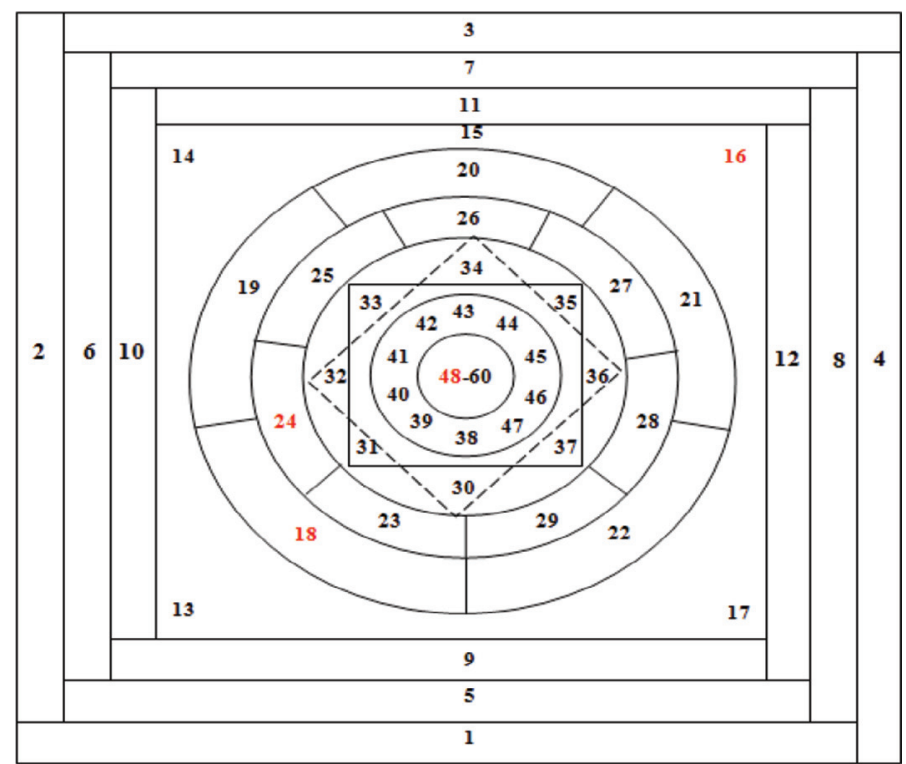

Figure 7: Levels of meditation according to Govinda [10].

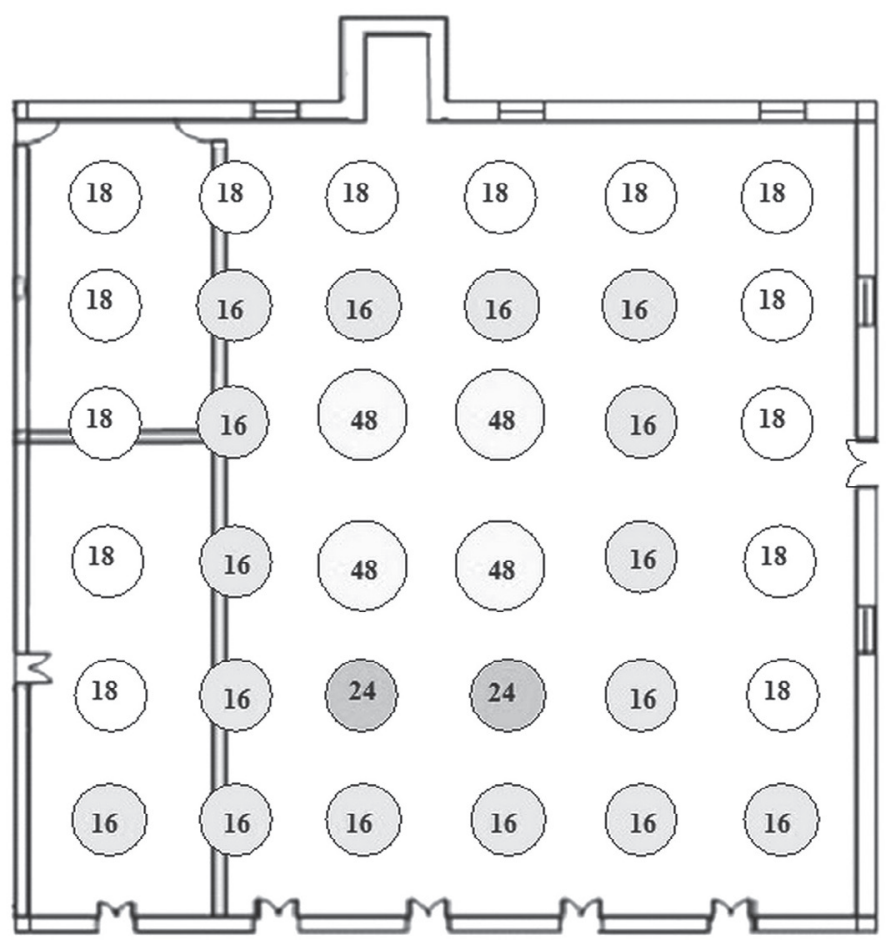

Figure 8: Columns' location simulation without pewastren and tomb. 
pewastren and tomb, there are likely an additional 12 columns in the mosque, totalling 36 columns (Fig. 8). It can be seen that the positions of the 36 columns in the mosque form a pattern that contains meanings describing the levels of meditation. The column arrangement pattern is centralised, similar to the circular pattern of the meditation levels. The main columns with 48 curved-rib column stumps are located in the centre of the mosque, which symbolises the highest achievement in the meditation process.

\section{CONCLUSION}

The quality of art and history of a building can be seen from the appearance and details of a building. The grassroots of a culture and religion can also be seen from the shape and decorative components of a typical building. The display of the elements of architecture and interior design of the BGM, particularly the basic shape of a five-tiered roof and the detail of the umpak with a number of curves, is based on the philosophy of earlier religions before Islam, that is, the Hindu-Buddhist philosophy. The finding of this study highlighted the HinduBuddhist philosophy later embedded with the Islamic philosophical approach. It became the finding of a deeper mix of philosophy compared with similar studies undertaken earlier. The philosophy found in this research can be derived from the architectural components of buildings in the Grand Mosque of Banten complex. This includes the basic shape and ornamentation of the tiered roof and the detail of the mosque column stump (umpak) located within the mosque, in particular the number of curves of the column stumps. The contribution of this study can be a reference for future research and should be able to contribute new knowledge about traditional mosques in Indonesia, especially in the case of the buildings in the complex of the Great Mosque of Banten, Banten Province, Indonesia. It can also provide a deeper understanding of the influence of various cultural and religious philosophies of the existence of traditional religious architecture in Indonesia.

\section{REFERENCES}

[1] Minaham, J., Ethnic Groups of South Asia and the Pasific: An Encyclopedia, ABCCLIO: Santa Barbara, CA, 2012.

[2] Tjandrasasmita, U., Arkeologi Islam Nusantara, KPG: Jakarta, pp. 10-19, 2009.

[3] Setyoningrum, Y., Thesis: Perubahan Arsitektur dan Interior Gereja Katholik di Yogyakarta pada Masa Kolonial Belanda: Sebuah Kajian Inkultirasi Budaya, ITB, Bandung, pp. 26-48, 2004.

[4] Ismunandar, K., Joglo: Arsitektur Rumah Tradisional Jawa, Effhar: Semarang, pp. 9-54, 1986.

[5] Tjahjono, G., Thesis: Cosmos, Center, and Duality in Javanese Architectural Tradition: The Symbolic Dimensions of House Shapes in Kota Gede and Surroundings, University of California, Berkeley, pp. 308-339, 1989.

[6] Kurdie, T.H., Personal communication, March 2011, Tokoh Masyarakat dan Arkeologi, Banten Lama, Indonesia.

[7] Bahauddin, A., The Songket Motifs: Between Reality and Belief. Tourism and Histories: Representations and Experiences, University of Lancashire: Preston, UK, pp. 1-13, 14, 16, 18-19, 19-21 June 2003.

[8] Snodgrass, A., The Symbolism of the Stupa, Cornell: New York, pp. 46-48, 1985.

[9] Yadi, A., Personal communication, 14, 15, 17, 18 March 2014, Pakar Filologi dan Sejarah Masjid Agung Banten, Banten Lama, Indonesia.

[10] Govinda, A.L., Psycho-cosmic Symbolism of the Buddhist Stupa, Dharma Publishing: Berkeley, CA, p. 13, 1976. 